\title{
Pre-Reducing Process Kinetics to Recover Metals from Nickel Leach Waste Using Chelating Resins
}

\author{
Amilton Barbosa Botelho Junior $\mathbb{D}^{1},{ }^{1}$ David Bruce Dreisinger, ${ }^{2}$ \\ Denise Crocce Romano Espinosa, ${ }^{1}$ and Jorge Alberto Soares Tenório ${ }^{1}$ \\ ${ }^{1}$ Department of Chemical Engineering, Polytechnic School of University of São Paulo, Sao Paulo, Brazil \\ ${ }^{2}$ Department of Materials Engineering, The University of British Columbia, Vancouver, Canada
}

Correspondence should be addressed to Amilton Barbosa Botelho Junior; amilton.barbosa20@gmail.com

Received 12 June 2018; Revised 12 July 2018; Accepted 30 July 2018; Published 9 October 2018

Academic Editor: Eric Guibal

Copyright ( 2018 Amilton Barbosa Botelho Junior et al. This is an open access article distributed under the Creative Commons Attribution License, which permits unrestricted use, distribution, and reproduction in any medium, provided the original work is properly cited.

\begin{abstract}
The main problem of the separation process from nickel mining using the ion exchange technique is the presence of iron, which precipitates in $\mathrm{pH}$ above 2.00 and causes coprecipitation of copper and cobalt. Chelating resins have the main advantage of being selected for a specific metal present in solution. Studies have been developed to increase the efficiency of metals recovery using chemical reduction and the ion exchange process to recover metals. The aim of this work was to use sodium sulfite as a reducing agent to convert $\mathrm{Fe}(\mathrm{III})$ to $\mathrm{Fe}(\mathrm{II})$. Chelating resins Lewatit ${ }^{\circledR} \mathrm{TP} 207$, selective for copper, and Lewatit ${ }^{\circledR}$ TP 220 , selective for nickel and cobalt, were studied. Batch experiments were performed to study the effect of $\mathrm{pH}$ with and without sodium sulfite. Results indicated that the industrial process has increased efficiency when the reducing process is applied.
\end{abstract}

\section{Introduction}

Nickel laterite represents $70 \%$ of nickel reserves and $40 \%$ of nickel production, mostly processed by the hydrometallurgical process, due to the fact that the nickel laterite process is more expensive and difficult than other ores [1-6]. The main problem for metals recovery, such as nickel, copper, and cobalt, from these ores is the high concentration of iron. Limonite layer, the first layer of the nickel laterite ore and processed by high-pressure acid leaching or atmospheric acid leaching using sulfuric acid, has $40-50 \%$ of iron approximately, while nickel concentration is $0.8-1.5 \%$ and cobalt concentration is $0.1-0.2 \%$ [7].

In order to separate iron from nickel laterite leach, Jiménez Correaé et al. studied chemical precipitation of Fe (III) and $\mathrm{Fe}$ (II) in a solution of nickel laterite using hydroxides. Results obtained show that, at $\mathrm{pH} 2.50,30 \%$ of iron and $20 \%$ of cobalt precipitate. At pH 3.00, $100 \%$ of iron, $60 \%$ of cobalt, and $20 \%$ of copper precipitate [8]. Another study realized by Chang et al. performed experiments to precipitate iron from nickel laterite leach by the oxidation process. Results show that there was loss of nickel to the residue with all iron. Nickel can be recovered from the residue using the weak acid solution, but more steps can turn the process impracticable [9].

Ion exchange process using chelating resins can be a solution to selectively recover metals. For this reason, Jiménez Correa et al. studied copper and nickel recovery using the chelating resin Dowex M4195 from nickel laterite leach waste. The chelating resin has the bis-picolylamine functional group, and results show that copper recovery was highly influenced by iron due to its high concentration (150 mg. $\mathrm{L}^{-1}$ of copper and $18000 \mathrm{mg} \cdot \mathrm{L}^{-1}$ of iron) [10]. Littlejohn and Vaughan [11] studied nickel and cobalt recovery using the chelating resin Lewatit ${ }^{\circledR}$ TP 220, with the same functional group of M4195, from nickel laterite tailings. Ferric iron was the most significant impurity adsorbed by resin, and results were obtained by Jiménez Correa et al. [10].

Zainol and Nicol studied five chelating resins with the iminodiacetate functional group to recover nickel and cobalt from nickel laterite leach tailings. The presence of iron, as well as chromium and aluminum, decreased resins 
efficiency, due to strong adsorption of these functional groups. In spite of all resins studied having the same functional group, results were different, and TP 207 MonoPlus had better results for nickel recovery [12]. Comparing metals recovery using Lewatit ${ }^{\circledR}$ TP 207 with the iminodiacetate functional group, copper recovery is higher than nickel in all $\mathrm{pH}$ values studied by Rudnicki et al. [13]. Metals recovery, both copper and nickel, increased when $\mathrm{pH}$ increases [13].

According to Littlejohn and Vaughan and Mendes and Martins, chelating resins with the iminodiacetate functional group are better to recover copper, and resins with the bispicolylamine functional group were more selective for nickel and cobalt than the others metals $[14,15]$.

In spite of chelating resins used to selectively recover metals, iron still is a problem to overcome. Botelho Junior et al. studied the difference between ferric iron and ferrous iron in nickel laterite leach waste for copper recovery using Lewatit ${ }^{\circledR}$ TP 207, in which chelating resin efficiency increases when iron is present as ferrous iron. In solution with $\mathrm{Fe}(\mathrm{III})$, copper recovery was $48.72 \%$, while solution with $\mathrm{Fe}$ (II) copper recovery was $61.32 \%$ [16-18]. A way to convert ferric iron to ferrous iron is using a reducing agent. Sodium dithionite and sodium metabisulfite were studied to convert ferric iron to ferrous iron of nickel laterite leach waste reducing the potential of the solution until $590 \mathrm{mV}(\mathrm{pH}$ $0.50-2.00)$ and $240 \mathrm{mV}(\mathrm{pH} 2.50-3.50)$. However, the problem is these reducing agents are dangerous in acid solutions, which can release hydrogen sulfide $\left(\mathrm{H}_{2} \mathrm{~S}\right)$, and these reducing agents can be added if dissolved in water before. The other problem is they are expensive [19-21].

Other reducing agents that can be used such as sodium thiosulfate or microorganismos have the same problem in acid solutions [22-26]. Nevertheless, sodium sulfite is a reducing agent that can be used in acid solutions. Liu et al. studied reductive stripping of ferric iron using sulfuric acid and sodium sulfite [27]. Luo et al. studied atmospheric leaching of nickel limonite with sulfuric acid using sodium sulfite as a reducing agent to facilitate nickel extraction, comparing the leaching process using only sulfuric acid. Results indicated that nickel extraction increases in presence of sodium sulfite, as well as iron extraction. Though the nickel extraction increased, the increase of the iron extraction still keeps the problem [28].

The goal of this work was to study the batch industrial process to recover copper, nickel, and cobalt using the ion exchange technique. Chelating resins Lewatit ${ }^{\circledR}$ TP 207, selective for copper with the iminodiacetate functional group, and Lewatit ${ }^{\circledR}$ TP 220 , selective for nickel and cobalt with bispicolylamine functional group, were studied. Sodium sulfite was used to reduce the potential of solution, converting ferric iron to ferrous iron, while the reducing process was studied before using sodium dithionite and sodium metabisulfite $[19,20,29]$. Three synthetic solutions were prepared to simulate real conditions of nickel laterite leach waste from the limonite ore. Solution 1 was used to study copper recovery, Solution 2 without copper was used to study nickel recovery; and Solution 3 without copper and nickel was used to study cobalt recovery. Effect of $\mathrm{pH}$ was studied between
pH 0.50 and 2.00, for solutions without sodium sulfite, and between pH 0.50 and 3.50, with sodium sulfite. Experiments were performed in a batch at $25^{\circ} \mathrm{C}$ and $150 \mathrm{rpm}$. Samples were analyzed using ICP-OES (Varian 725ES).

\section{Materials and Methods}

2.1. Materials. Composition of synthetics solutions is present in Table 1. Sulfate salts of each metal were dissolved in deionized water, and the $\mathrm{pH}$ was adjusted with sulfuric acid concentrated PA. Three different solutions were prepared: Solution 1 was prepared with all metals that compose the nickel laterite leach, Solution 2 was prepared without copper, and Solution 3 was prepared without copper and nickel. Therefore, it is a possible study effect of other metals presented in the leach solution for copper, nickel, and cobalt adsorption in three steps.

Two different chelating resins were studied: Lewatit ${ }^{\circledR} \mathrm{TP}$ 207, for experiments performed using Solution 1, and Lewatit ${ }^{\circledR}$ TP 220, for experiments performed using Solutions 2 and 3. TP 207 is a cationic resin with the iminodiacetate functional group, crosslinked polystyrene macroporous matrix, $\mathrm{pH}$ range $0-14$ and density $1.17 \mathrm{~g} \cdot \mathrm{mL}^{-1}$ [30]. The theoretical selectivity order for this resin is $\mathrm{Fe}(\mathrm{III})>\mathrm{Cu}$ (II) $>\mathrm{Ni}(\mathrm{II})>\mathrm{Zn}(\mathrm{II})>\mathrm{Fe}$ (II) $>\mathrm{Mn}$ (II) $>\mathrm{Mg}$ (II) [13]. TP 220 is also a cationic resin, but with the bis-picolylamine functional group, crosslinked polystyrene macroporous matrix, density $1.1 \mathrm{~g} \cdot \mathrm{mL}^{-1}$. The theoretical selectivity order for this resin is $\mathrm{Cu}(\mathrm{II})>\mathrm{Ni}$ (II) $>\mathrm{Fe}$ (III) $>\mathrm{Co}(\mathrm{II})>\mathrm{Mn}(\mathrm{II})>\mathrm{K}(\mathrm{I})>\mathrm{Ca}(\mathrm{II})$ $>\mathrm{Na}(\mathrm{I})>\mathrm{Mg}(\mathrm{II})>\mathrm{Al}(\mathrm{III})[11,31]$.

\subsection{Method}

2.2.1. Pre-Reducing Process. Botelho Junior et.al. studied the reducing process using sodium dithionite and sodium metabisulfite to convert $\mathrm{Fe}$ (III) to $\mathrm{Fe}$ (II) from the synthetic solution of nickel laterite leach. Effect of time, $\mathrm{pH}$, and temperature was studied. Temperature decreased ferric iron chemical conversion, probably due to the reducing agent composition. The effect of time was studied until 96 hours, and after $120 \mathrm{~min}$, the reaction reaches equilibrium, until $480 \mathrm{~min}$, and then decreased from $95 \%$ to $80 \%$ after 1144 min. Conversion of $\mathrm{Fe}(\mathrm{III})$ to $\mathrm{Fe}(\mathrm{II})$ in $100 \%$ was performed decreasing the potential until $590 \mathrm{mV}$, at $\mathrm{pH}$ $0.50-2.00$, and $240 \mathrm{mV}$, at $\mathrm{pH} 2.50-3.50$. For synthetic solution with all metals of nickel laterite leach, ferric iron conversion is $80 \%[19,20,29]$.

Thus, the pre-reducing process was performed during $120 \mathrm{~min}$ adding sodium sulfite in order to decrease the potential until $590 \mathrm{mV} \mathrm{SHE} \mathrm{(standard} \mathrm{hydrogen} \mathrm{electrode),}$ $\mathrm{pH} 0.50-2.00$, and $240 \mathrm{mV} \mathrm{SHE}, \mathrm{pH} 2.50-3.50$, at $25^{\circ} \mathrm{C}$ in $150 \mathrm{rpm}$.

2.2.2. Ion Exchange Experiments. Ion exchange experiments were performed in flasks of $100 \mathrm{~mL}$ with $50 \mathrm{~mL}$ of solution and $0.50 \mathrm{~mL}$ of resin in $150 \mathrm{rpm}$ at $25^{\circ} \mathrm{C}$ during $120 \mathrm{~min}$. The effect of time was studied without the pre-reducing process between 30 and $480 \mathrm{~min}$ at $\mathrm{pH} 0.50$ for Solution 1, with 
TABLe 1: Metals concentration for batch experiments for Solution 1, Solution 2, and Solution $3 \mathrm{in} \mathrm{mg} \cdot \mathrm{L}^{-1}$.

\begin{tabular}{|c|c|c|c|c|c|c|c|c|c|c|}
\hline & \multicolumn{10}{|c|}{ Metals } \\
\hline & - & Al & Co & $\mathrm{Cu}$ & $\mathrm{Cr}$ & $\mathrm{Fe}$ & $\mathrm{Mg}$ & Mn & $\mathbf{N i}$ & $\mathrm{Zn}$ \\
\hline \multirow{3}{*}{ Conc. (mg. $\left.\mathrm{L}^{-1}\right)$} & Solution 1 & 4101 & 78 & 146 & 195 & 18713 & 7774 & 387 & 2434 & 36 \\
\hline & Solution 2 & 4101 & 78 & - & 195 & 18713 & 7774 & 387 & 2434 & 36 \\
\hline & Solution 3 & 4101 & 78 & - & 195 & 18713 & 7774 & 387 & - & 36 \\
\hline
\end{tabular}

Lewatit $^{\circledR}$ TP 207, and Solution 2, with Lewatit ${ }^{\circledR}$ TP 220. The effect of $\mathrm{pH}$ was studied between $\mathrm{pH} 0.50$ and 3.50.

Resins were washed using hydrochloric acid $6 \mathrm{~mol} \cdot \mathrm{L}^{-1}$ and sodium hydroxide $1 \mathrm{~mol} \cdot \mathrm{L}^{-1}$ for three times using water deionized between each step. Sulfuric acid $1 \mathrm{~mol} \cdot \mathrm{L}^{-1}$ was used after wash. Sulfuric acid concentrated PA and sodium hydroxide pellet were used to correct the $\mathrm{pH}$ [32].

In order to quantify the cations adsorbed, Equation (1) was used, where $q_{t}$ is the capacity of the ion adsorbed in time $t$ in mass of the ion per mass of resin $\left(\mathrm{mg}^{-1} \mathrm{~g}^{-1}\right), C_{0} \cdot e \cdot C_{t}$ are concentrations of ions in time $=0$ and time $=t\left(\mathrm{mg} \cdot \mathrm{L}^{-1}\right), v$ is the volume of solution $(L)$, and $m$ is the mass of the resin $(\mathrm{g})$ $[13,33]$. Equation (2) was used to quantify the coefficient of distribution of ion, which one is the measure of the effectiveness of ion adsorption from solution [32]. Equation (3) was used to quantify the adsorbed ion, in percentage:

$$
\begin{aligned}
q_{t} & =\left(C_{0}-C_{t}\right) \times \frac{v}{m}, \\
K d & =\frac{q_{\mathrm{e}}}{C_{t}} \times 1000, \\
\% S & =\frac{\left(C_{0}-C_{t}\right)}{C_{0}} \times 100 \% .
\end{aligned}
$$

The $\mathrm{pH}$ was measured using electrode $\mathrm{Ag} / \mathrm{AgCl}$ (Sensoglass), and electrode ORP (oxidation reduction potential) was used to measure the potential in solution. Samples were analyzed using ICP-EOS (Varian 725ES Optical Emission Spectrometer).

\section{Results and Discussion}

Figure 1 presents Pourbaix's diagram constructed using Hydra-Medusa software in experimental conditions for the $\mathrm{Fe}-\mathrm{S}-\mathrm{H}_{2} \mathrm{O}$ system, where the conversion of $\mathrm{Fe}(\mathrm{III})$ to $\mathrm{Fe}(\mathrm{II})$ is $100 \%$ after $590 \mathrm{mV}$ between $\mathrm{pH} 0.50$ and 2.00 , and it is after $240 \mathrm{mV}$ between $\mathrm{pH} 2.50$ and 3.50. However, presence of the other metals decreases the reducing process efficiency. In acid medium with sulfuric acid, sodium sulfite reacts with $\mathrm{H}^{+}$to form $\mathrm{H}_{2} \mathrm{SO}_{3}$, as presented in Equation (4), in which $k_{1}=1.54 \times 10^{-2}$ and $k_{2}=1.02 \times 10^{-7}$. Besides, sodium dithionite and sodium sulfite are different, and both dissociate to form sodium bisulfite, which is the main responsible for the reducing process in solution, but sodium dithionite also dissociates to form sodium thiosulfate [27, 34-37].

$$
\mathrm{SO}_{2(\mathrm{aq})}+\mathrm{H}_{2} \rightleftharpoons \mathrm{H}^{+}+\mathrm{HSO}_{3}^{-} \rightleftharpoons \mathrm{H}^{+}+\mathrm{SO}_{3}^{-2}
$$

Another problem about sodium dithionite is that acid medium can be dissociated to form sulphur and hydrogen sulfide, being the last extremely dangerous [38]. Besides,

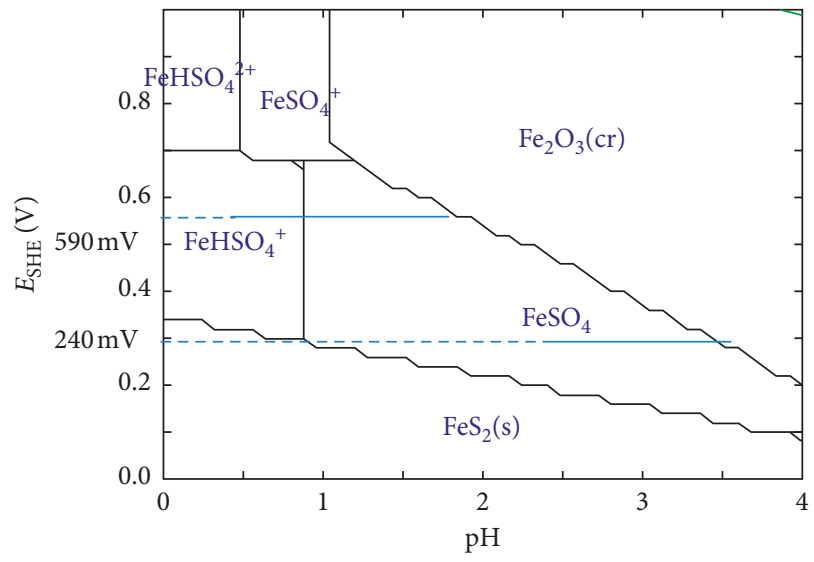

Figure 1: Pourbaix's diagram of $\mathrm{Fe}-\mathrm{S}-\mathrm{H}_{2} \mathrm{O}$ constructed using Hydra-Medusa software at $25^{\circ} \mathrm{C}$.

sodium dithionite, sodium thiosulfate, and sodium bisulfate are dangerous because of same problem in the acid medium, using them only in the basic medium $[23,39]$.

3.1. Effect of Time. The effect of time was studied using Solution 1 and Solution 2 without the pre-reducing process at $25^{\circ} \mathrm{C}$ and $\mathrm{pH}$ 0.50. Results for copper (Solution 1) and nickel (Solution 2) recovery are present in Figure 2 and indicate that the reaction reached equilibrium after $120 \mathrm{~min}$, in which Solution 1 was in contact of Lewatit ${ }^{\circledR}$ TP 207 and Solution 2 with Lewatit ${ }^{\circledR}$ TP 220. Iron was the metal highest adsorbed in mg per $\mathrm{g}$ of resin $\left(151 \mathrm{mg} \cdot \mathrm{g}^{-1}\right)$, while copper was $1.67 \mathrm{mg} \cdot \mathrm{g}^{-1}$, due to high concentration of $\mathrm{H}^{+}$in solution at $\mathrm{pH} 0.50$. For Solution 2, iron was also in this case the highest metal adsorbed $\left(85 \mathrm{mg} \cdot \mathrm{g}^{-1}\right)$, while nickel was $10.87 \mathrm{mg} \cdot \mathrm{g}^{-1}$. Experiments to study the effect of $\mathrm{pH}$ in the ion exchange process were performed during $120 \mathrm{~min}$.

3.2. Effect of $p H$. The effect of $\mathrm{pH}$ in chelating resin with the iminodiacetate functional group can be seen in Figure 3. At $\mathrm{pH}$ 2, high concentration of $\mathrm{H}^{+}$in the functional group repulses cations in solution due to protonation of the functional group, where high competition between $\mathrm{H}^{+}$and cations occurs by the functional group. At $\mathrm{pH} 2-4, \mathrm{H}^{+}$and cations present in the solution still compete for the chelating resin functional group, the latter being deprotonated. In Figure 3, at $\mathrm{pH} 7$, carboxylic acid of the functional group is deprotonated, and at $\mathrm{pH} \mathrm{12,} \mathrm{the} \mathrm{iminodiacetate} \mathrm{functional}$ group is totally deprotonated. However, although the last situation is the most favorable to recover cations due to no presence of $\mathrm{H}^{+}$in the functional group, metals in general 


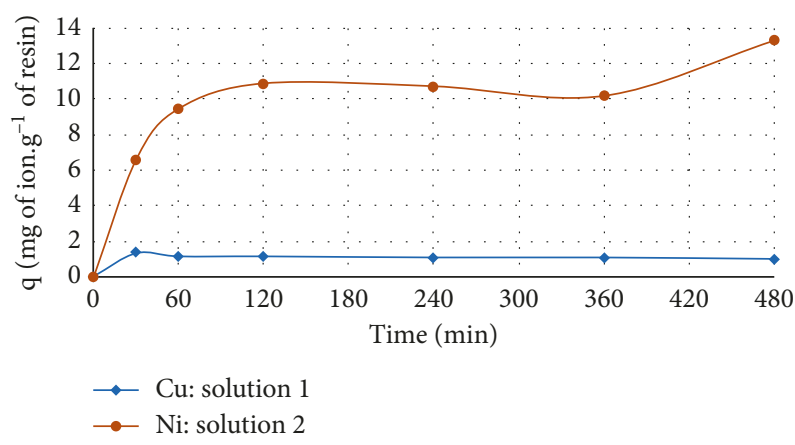

FIgUre 2: Results of effect of time of Solution 1 and Solution 2.

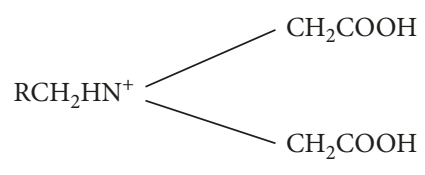

$\mathrm{pH}=2.21$

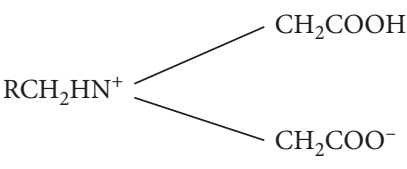

$\mathrm{pH}=3.99$

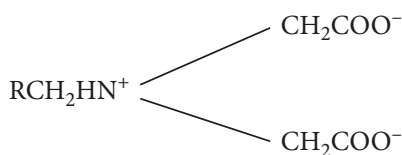

$\mathrm{pH}=7.41$

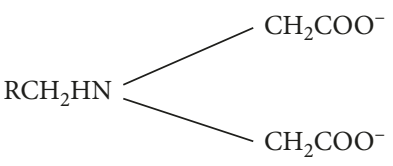

$\mathrm{pH}=12.3$

FIGURE 3: Effect of $\mathrm{pH}$ in the iminodiacetate functional group [40].

precipitate at $\mathrm{pH}$, which causes working $\mathrm{pH}$ to be totally dependent of solution characteristics $[12,13,40]$.

Results for metals recovery with and without the prereducing process are present below. Effect of $\mathrm{pH}$ without the pre-reducing process above $\mathrm{pH} 2.00$ was not studied, because from this $\mathrm{pH}$, iron will precipitate with copper and cobalt $[8,41]$. Figure 4 presents results for copper recovery in Solution 1 by the iminodiacetate resin Lewatit ${ }^{\circledR}$ TP 207. It is observed that copper recovery increased for Solution 1 with the pre-reducing process. At $\mathrm{pH} 0.50$, copper recovery was $9.66 \%$ without the pre-reducing process, while using sodium sulfite to convert $\mathrm{Fe}(\mathrm{III})$ to $\mathrm{Fe}(\mathrm{II})$, copper recovery at $\mathrm{pH} 0.50$ was $16.67 \%$. At pH 2.00, both had highest copper recovery. In solution without sodium sulfite, copper recovery was $41.43 \%$, and with sodium sulfite as a reducing agent, copper recovery was $68.57 \%$.

Botelho Junior et al. studied the effect of presence of Fe (III) and $\mathrm{Fe}$ (II) to recover copper from nickel laterite leach using resin with the iminodiacetate functional group. Results show that when iron is $\mathrm{Fe}(\mathrm{II})$, copper recovery is higher than when Fe(III) is present in solution [18]. This can occur because the iminodiacetate functional group has high affinity for $\mathrm{Fe}$ (III) $[15,42-44]$, once it was the highest metal recovery among all in $\mathrm{mg} \cdot \mathrm{L}^{-1}$ in all $\mathrm{pH}$ studied.

Figure 5 shows results of metals recovery of Solution 2 with Lewatit ${ }^{\circledR}$ TP 220, chelating resin with the bispicolylamine functional group. At $\mathrm{pH} 0.50-2.00$, chelating resin was more selective for nickel than other metals in both solution, except for solution without the pre-reducing process at $\mathrm{pH} 0.50$. At $\mathrm{pH} 2.50$ and 3.00, in solution with the pre-reducing process, cobalt was the metal more selective by the resin, followed by zinc and nickel. At $\mathrm{pH} 3.50$, however, chelating resin was more selective for zinc, followed by nickel and cobalt. This phenomenon was also seen in Solution 1 experiments, where chelating resins selective order changes for different $\mathrm{pH}$ values and also with the prereducing process. The difference in the selective order for solution with and without the reducing process can be explained due to conversion of $\mathrm{Fe}(\mathrm{III})$ to $\mathrm{Fe}(\mathrm{II})$.

Chelating resin for Solution 2 with the pre-reducing process between $\mathrm{pH} 0.50$ and 2.00 was more selective for nickel than cobalt and zinc. At pH 2.50 and 3.00, the resin was more selective for cobalt, and at $\mathrm{pH} 3.50$, chelating resin was more selective for nickel and zinc, simultaneously.

The effect of $\mathrm{pH}$ for cobalt and zinc recovery from Solution 3 by the bis-picolylamine resin is shown in Figure 6. Chelating resin has high selective for cobalt between $\mathrm{pH} 0.50$ and 2.00 in both situations. However, at $\mathrm{pH} 2.50$ and 3.00, zinc was more selective by the resin than cobalt, and both were almost not recovered by the resin at $\mathrm{pH} 3.50$. The change in the order of selectivity was also observed. Figure 7 presents coefficient distribution of copper, nickel, cobalt, and zinc in Solutions 1, 2, and 3 with the pre-reducing process.

It is possible seen that copper coefficient distribution, in Solution 1, was maximum $\left(186 \mathrm{~mL} \cdot \mathrm{g}^{-1}\right)$ at $\mathrm{pH} 2.00$, indicating that the chelating resin Lewatit ${ }^{\circledR}$ TP 207 with the iminodiacetate functional group was more selective for copper in this $\mathrm{pH}$. In Solution 2, nickel coefficient distribution was maximum at $\mathrm{pH} 3.50\left(121 \mathrm{~mL} \cdot \mathrm{g}^{-1}\right)$; however, at the same $\mathrm{pH}$, zinc had higher coefficient distribution $\left(160 \mathrm{~mL} \cdot \mathrm{g}^{-1}\right)$ than nickel, indicating Lewatit ${ }^{\circledR}$ TP 220 with the bis-picolylamine functional group was more selective for zinc than nickel. In the meantime, cobalt had higher coefficient distribution at $\mathrm{pH} 3.50\left(61 \mathrm{~mL} \cdot \mathrm{g}^{-1}\right)$ than the other $\mathrm{pH}$ values, which is seen in Figure 5, where copper recovery was maximum at pH 3.5 as well as nickel and zinc. For Solution 2, the chelating resin was more selective for nickel at pH $2.00\left(43 \mathrm{~mL} \cdot \mathrm{g}^{-1}\right.$ for nickel and $15 \mathrm{~mL} \cdot \mathrm{g}^{-1}$ for zinc and cobalt), where nickel recovery was $32.55 \%$ and zinc and 


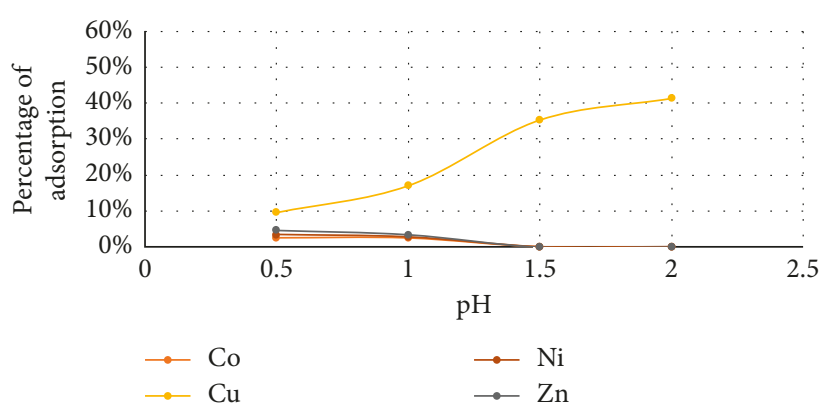

(a)

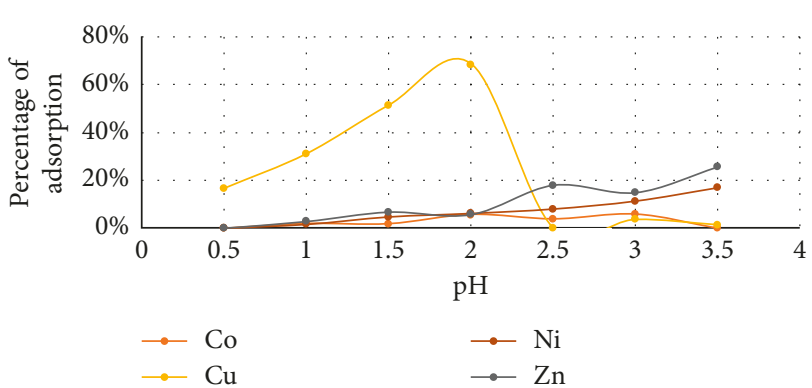

(b)

FIGURE 4: Effect of $\mathrm{pH}$ in Solution 1 by iminodiacetate resin (a) without and (b) with the pre-reducing process.

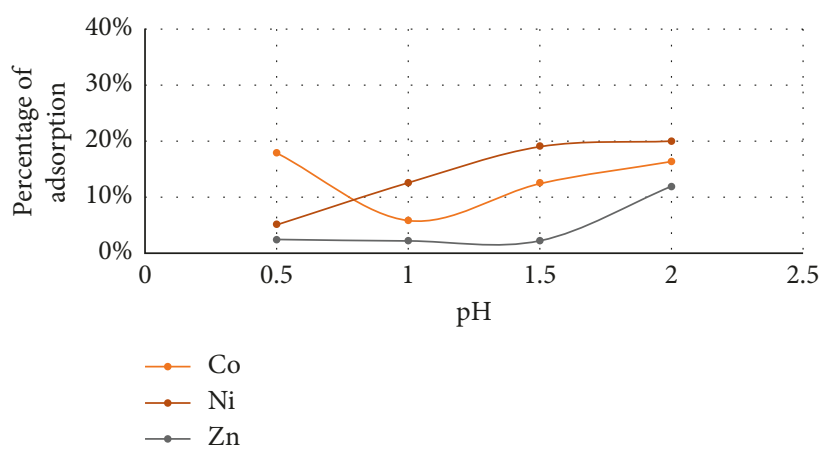

(a)

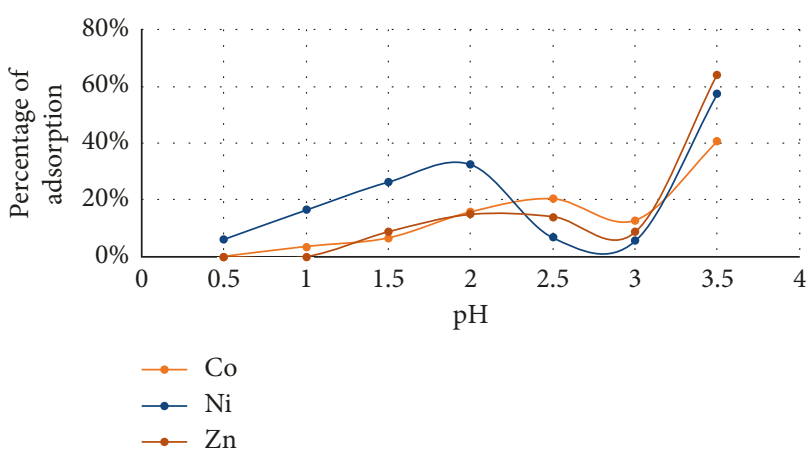

(b)

FIgURE 5: Effect of $\mathrm{pH}$ in Solution 2 by the bis-picolylamine resin (a) without and (b) with the pre-reducing process.

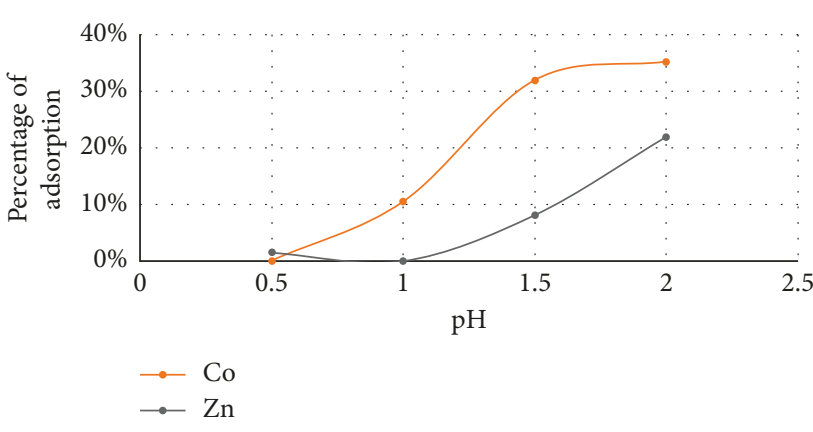

(a)

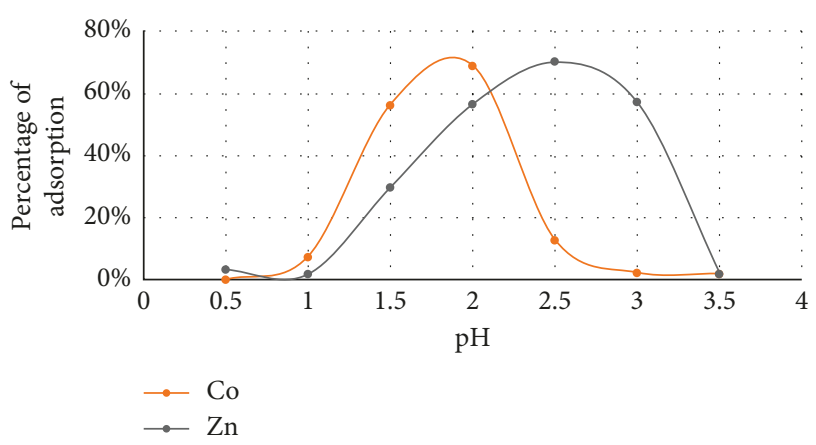

(b)

Figure 6: Effect of $\mathrm{pH}$ in Solution 3 by the bis-picolylamine resin (a) without and (b) with the pre-reducing process.

cobalt, $14.86 \%$. For Solution 3, cobalt coefficient distribution was maximum at $\mathrm{pH} 2.00\left(198 \mathrm{~mL} \cdot \mathrm{g}^{-1}\right)$, being resin more selective for this metal than others, and at $\mathrm{pH} 2.50$, zinc coefficient distribution was maximum $\left(206 \mathrm{~mL} \cdot \mathrm{g}^{-1}\right)$.

Studies to recover metals from nickel laterite leach using chelating resins indicated that resins with the iminodiacetate functional group are better to recover copper, while in order to recover nickel and cobalt resins with bis-picolylamine are better $[45,46]$. In experiments performed using Solution 1, Lewatit $^{\circledR}$ TP 207 was more selective for copper, while experiments performed with Solutions 2 and 3 using Lewatit ${ }^{\circledR}$
TP 220 cobalt and nickel were selectively recovered. Zinc was also selectively recovered depending on the $\mathrm{pH}$ value.

\section{Conclusion}

The aim of this work was to study the batch industrial process for metals recovery using two different chelating resins from synthetic solution of nickel laterite leach. Sodium sulfite was used in order to reduce $\mathrm{Fe}$ (III) to $\mathrm{Fe}(\mathrm{II})$. Results indicated that Lewatit ${ }^{\circledR}$ TP 207 was more selective for copper than the other metals, due to its functional group, 


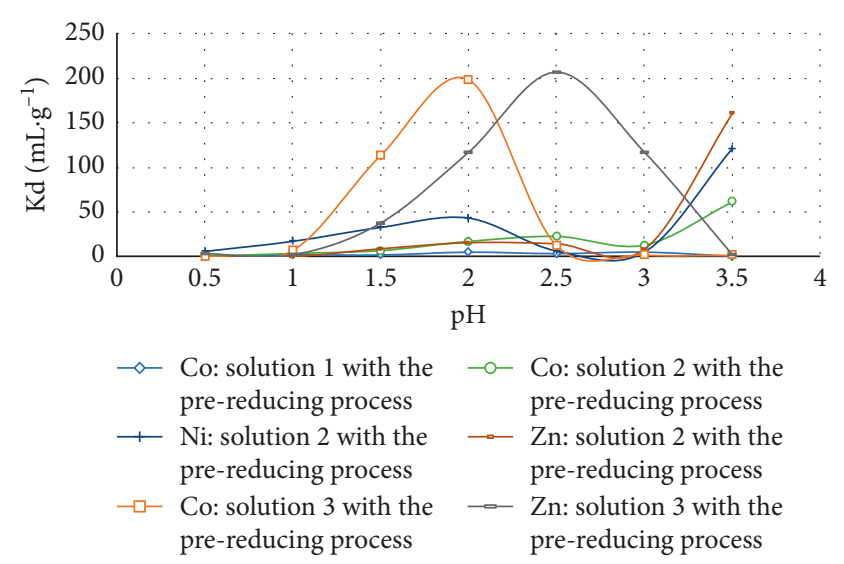

FIgURE 7: Coefficient distribution of copper, nickel, cobalt, and zinc with the pre-reducing process.

and Lewatit ${ }^{\circledR}$ TP 220 was more selective for cobalt and nickel. Sodium sulfite increased metals recovery because chelating resins were less selective for ferrous iron than ferric iron, and $\mathrm{pH}$ can be increased without ferric iron precipitation, due to the fact that, while increasing $\mathrm{pH}$, the concentration of $\mathrm{H}^{+}$decreases, as well as competition between $\mathrm{H}^{+}$and metals in solution for the functional group of chelating resin. Another reason than can be explain the metals recovery raise is that ferrous iron occupies less active sites on the chelating resin than ferric iron. In all the solutions studied, metals recovery was higher after the prereducing process. A change in the selectivity order of resins was observed comparing with and without the pre-reducing process, which may be caused by conversion of $\mathrm{Fe}$ (III) to Fe (III) and also by changing the $\mathrm{pH}$. Pre-reducing process using sodium dithionite and sodium metabisulfite was studied before, but the use of sodium sulfite as a cheap and secure option can make the process economically viable and secure. Industrial process can be a benefit for the process involving chemical reducing and ion exchange process, in which metals recovery increases comparatively without the reducing process. Column experiments are the next step to simulate fixed-bed reactors for the continuum process.

\section{Data Availability}

No data were used to support this study. Please feel comfortable to contact the corresponding author if any doubt comes up.

\section{Conflicts of Interest}

The authors declare that there are no conflicts of interest regarding the publication of this paper.

\section{Acknowledgments}

The authors acknowledge the São Paulo Research Foundation (FAPESP) (nos. 2012/51871-9, 2016/05527-5, and 2017/06563-8) and CAPES for financial support. They also acknowledge the University of British Columbia and University of São Paulo.

\section{References}

[1] F. K. Crundwell, M. S. Moats, V. Ramachandran, T. G. Robinson, and W. G. Davenport, Extractive Metallurgy of Nickel, Cobalt and Platinum-Group Metals, Elsevier, Oxford, UK, 2011, http://linkinghub.elsevier.com/retrieve/pii/ B9780080968094100012.

[2] G. M. Mudd, "Global trends and environmental issues in nickel mining: sulfides versus laterites," Ore Geology Reviews, vol. 38, no. 1-2, pp. 9-26, 2010.

[3] G. M. Mudd and S. M. Jowitt, "A detailed assessment of global nickel resource trends and endowments," Economic Geology, vol. 109, no. 7, pp. 1813-1841, 2014.

[4] A. D. Dalvi, W. G. Bacon, and R. C. Osborne, "The past and the future of nickel laterites," in Proceedings of PDAC 2004 International Convention, pp. 1-27, Toronto, Canada, January 2004.

[5] T. F. Torries, "Comparative costs of nickel sulphides and laterites," Resources Policy, vol. 21, no. 3, pp. 179-187, 1995.

[6] G. M. Mudd, "Nickel sulfide versus laterite: the hard sustainability challenge remains," in Proceedings of 48th Annual Conference of Metallurgists, pp. 1-10, Ontario, Canada, August 2009.

[7] A. Oxley and N. Barcza, "Hydro-pyro integration in the processing of nickel laterites," Minerals Engineering, vol. 54, pp. 2-13, 2013.

[8] M. M. Jiménez Correa, P. Aliprandini, J. A. S. Tenório, and D. C. R. Espinosa, "Precipitation of metals from liquor obtained in nickel mining," in REWAS 2016: Towards Materials Resource Sustainability, R. E. Kirchain, Ed., pp. 333-338, Springer, Cham, Switzerland, 2016.

[9] Y. Chang, X. Zhai, B. Li, and Y. Fu, "Removal of iron from acidic leach liquor of lateritic nickel ore by goethite precipitate," Hydrometallurgy, vol. 101, no. 1-2, pp. 84-87, 2010.

[10] M. M. Jiménez Correa, P. Aliprandini, F. P. C. Silvas, J. A. S. Tenório, D. Dreisinger, and D. C. R. Espinosa, "Nickel and copper adsorption from acidic sulfate medium by ion exchange," in Proceedings of Conference of Metallurgists hosting World Gold and Nickel Cobalt, Canadian Institute of Mining, Metallurgy and Petroleum, Vancouver, Canada, August 2017.

[11] P. Littlejohn and J. Vaughan, "Recovery of nickel and cobalt from laterite leach tailings through resin-in-pulp scavenging and selective ammoniacal elution," Minerals Engineering, vol. 54, pp. 14-20, 2013.

[12] Z. Zainol and M. J. Nicol, "Comparative study of chelating ion exchange resins for the recovery of nickel and cobalt from laterite leach tailings," Hydrometallurgy, vol. 96, no. 4, pp. 283-287, 2009.

[13] P. Rudnicki, Z. Hubicki, and D. Kołodyńska, "Evaluation of heavy metal ions removal from acidic waste water streams," Chemical Engineering Journal, vol. 252, pp. 362-373, 2014.

[14] P. Littlejohn and J. Vaughan, "Selectivity of commercial and novel mixed functionality cation exchange resins in mildly acidic sulfate and mixed sulfate-chloride solution," Hydrometallurgy, vol. 121-124, pp. 90-99, 2012.

[15] F. D. Mendes and A. H. Martins, "Selective sorption of nickel and cobalt from sulphate solutions using chelating resins," International Journal of Mineral Processing, vol. 74, no. 1-4, pp. 359-371, 2004. 
[16] D. Kołodyńska, W. Sofińska-Chmiel, E. Mendyk, and Z. Hubicki, "DOWEX M 4195 and LEWATIT ${ }^{\circledR}$ MonoPlus TP 220 in heavy metal ions removal from acidic streams," Separation Science and Technology, vol. 49, no. 13, pp. 2003-2015, 2014.

[17] D. S. Stefan and I. Meghea, "Mechanism of simultaneous removal of $\mathrm{Ca}^{2+}, \mathrm{Ni}^{2+}, \mathrm{Pb}^{2+}$ and $\mathrm{Al}^{3+}$ ions from aqueous solutions using Purolite ${ }^{\circledR}$ S930 ion exchange resin," Comptes Rendus Chimie, vol. 17, no. 5, pp. 496-502, 2014.

[18] A. B. Botelho Junior, M. M. Jiménez Correa, D. C. R. Espinosa, and J. A. S. Tenório, "Influência do Fe(III) no lixiviado de rejeito de níquel no processo de troca-iônica," Tecnologia em Metalurgia, Materiais e Mineração, p. 10, 2018.

[19] A. B. Botelho Junior, M. M. Jimenez, D. C. R. Espinosa, and J. A. S. Tenório, "Redução química de Fe(III) em resíduo de mineração de níquel para recuperação de metais utilizando resinas de troca-iônica," in Proceedings of $22^{\circ}$ Congresso Brasileiro de Engenharia e Ciência dos Materiais, pp. 45434553, Natal, Brazil, November 2016.

[20] A. B. Botelho Junior, M. M. Jiménez Correa, D. C. R. Espinosa, and J. A. S. Tenório, "Chemical reduction of Fe(III) in nickel lateritic wastewater to recover metals by ion exchange," in The Minerals, Metals \& Materials Series, pp. 467-472, Springer, Berlin, Germany, 2017.

[21] A. B. Botelho Junior, M. M. Jiménez Correa, D. C. R. Espinosa, and J. A. S. Tenório, "Precipitação seletiva de cobre a partir de resíduo de mineração de níquel," in Proceedings of Conference: XXVII Encontro Nacional de Tratamento de Minérios e Metalurgia Extrativa, pp. 1-5, Belém, Brazil, November 2017.

[22] I. S. Chung and Y. Y. Lee, "Effect of oxygen and redox potential on d-xylose fermentation by non-growing cells of Pachysolen tannophilus," Enzyme and Microbial Technology, vol. 8, no. 8, pp. 503-507, 1986.

[23] K. Wejman-Gibas, T. Chmielewski, K. Borowsi, K. Gibas, M. Jeziorek, and J. Wodka, "Thiosulfate leaching of silver from a solid residue after pressure leaching of industrial copper sulfides flotation," Physicochemical Problems of Mineral Processing, vol. 51, no. 2, pp. 601-610, 2015.

[24] D. M. Puente-Siller, J. C. Fuentes-Aceituno, and F. NavaAlonso, "A kinetic-thermodynamic study of silver leaching in thiosulfate-copper-ammonia-EDTA solutions," Hydrometallurgy, vol. 134-135, pp. 124-131, 2013.

[25] D. Zipperian, S. Raghavan, and J. P. Wilson, "Gold and silver extraction by ammoniacal thiosulfate leaching from a rhyolite ore," Hydrometallurgy, vol. 19, no. 3, pp. 361-375, 1988.

[26] C. Cameselle, M. José Núñez, J. M. Lema, and J. Pais, "Leaching of iron from kaolins by a spent fermentation liquor: Influence of temperature, $\mathrm{pH}$, agitation and citric acid concentration," Journal of Industrial Microbiology, vol. 14, no. 34, pp. 288-292, 1995.

[27] Y. Liu, S. H. Nam, and M. Lee, "Stripping of Fe(III) from the loaded mixture of D2EHPA and TBP with sulfuric acid containing reducing agents," Bulletin of the Korean Chemical Society, vol. 35, no. 7, pp. 2109-2113, 2014.

[28] J. Luo, G. Li, M. Rao, Z. Peng, Y. Zhang, and T. Jiang, "Atmospheric leaching characteristics of nickel and iron in limonitic laterite with sulfuric acid in the presence of sodium sulfite," Minerals Engineering, vol. 78, pp. 38-44, 2015.

[29] A. B. Botelho Junior, M. M. Jiménez Correa, D. C. R. Espinosa, and J. A. S. Tenório, "Study of reducing process of iron in leachate from nickel mining waste," Brazilian Journal of Chemical Engineering, 2018.
[30] Lanxess, Product Information-Lewatit ${ }^{\circledR} T P$ 207, Lanxess, Cologne, Germany, 2011, http://www.lenntech.com/Datasheets/Lewatit-TP-207-L.pdf.

[31] Lanxess, Product Information-ewatit ${ }^{\circledR}$, MonoPlus TP, Vol. 220, Lanxess, Cologne, Germany, 2011.

[32] M. L. Inamuddin, Ion Exchange Technology I, Springer, New York, NY, USA, 1st edition, 2012.

[33] Z. Yu, T. Qi, J. Qu, L. Wang, and J. Chu, "Removal of Ca(II) and $\mathrm{Mg}$ (II) from potassium chromate solution on Amberlite IRC 748 synthetic resin by ion exchange," Journal of Hazardous Materials, vol. 167, no. 1-3, pp. 406-412, 2009.

[34] B. Jung, R. Sivasubramanian, B. Batchelor, and A. AbdelWahab, "Chlorate reduction by dithionite/UV advanced reduction process," International Journal of Environmental Science and Technology, vol. 14, no. 5, pp. 123-134, 2017.

[35] M. Wayman and W. J. Lem, "Decomposition of aqueous dithionite. Part II. A reaction mechanism for the decomposition of aqueous sodium dithionite," Canadian Journal of Chemistry, vol. 48, no. 5, pp. 782-787, 1970.

[36] V. Cermak and M. Smutek, "Mechanism of decomposition of dithionite in aqueous solutions," Collection of Czechoslovak Chemical Communications, vol. 40, no. 11, pp. 3241-3264, 1975.

[37] C. W. Li, J. H. Yu, Y. M. Liang et al., "Ni removal from aqueous solutions by chemical reduction: impact of $\mathrm{pH}$ and pe in the presence of citrate," Journal of Hazardous Materials, vol. 320, pp. 521-528, 2016.

[38] F. A. N. G. Da Silva, F. M. D. S. Garrido, M. E. Medeiros et al., "Alvejamento químico de caulins brasileiros: efeito do potencial eletroquímico da polpa e do ajuste do $\mathrm{pH}$," Química Nova, vol. 34, no. 2, pp. 262-267, 2011.

[39] J. L. Deutsch, Fundamental Aspects of Thiosulfate Leaching of Silver Sulfide in the Presence of Additives, University of British Columbia, Vancouver, Canada, 2012.

[40] Z. Zainol and M. J. Nicol, "Ion-exchange equilibria of $\mathrm{Ni}^{2+}$, $\mathrm{Co}^{2+}, \mathrm{Mn}^{2+}$ and $\mathrm{Mg}^{2+}$ with iminodiacetic acid chelating resin Amberlite IRC 748," Hydrometallurgy, vol. 99, no. 3-4, pp. 175-180, 2009.

[41] P. Aliprandini, M. Correa, A. Santanilla, J. Tenório, and D. C. R. Espinosa, "Precipitation of metals from synthetic laterite nickel liquor by $\mathrm{NaOH}$," in Proceedings of 8 th International Seminar on Process Hydrometallurgy, pp. 1-8, Santiago, Chile, June 2016.

[42] F. D. Mendes and A. H. Martins, "Recovery of nickel and cobalt from acid leach pulp by ion exchange using chelating resin,” Minerals Engineering, vol. 18, no. 9, pp. 945-954, 2005.

[43] F. D. Mendes and A. H. Martins, "Selective nickel and cobalt uptake from pressure sulfuric acid leach solutions using column resin sorption," International Journal of Mineral Processing, vol. 77, no. 1, pp. 53-63, 2005.

[44] Z. Hubicki and D. Kołodyńska, "Selective removal of heavy metal ions from waters and waste waters using ion exchange methods," in Ion Exchange Technologies, IntechOpen Limited, London, UK, pp. 193-240, 2012.

[45] Z. Hubicki, M. Geca, and D. Kołodyńska, "The effect of the presence of metatartaric acid on removal effectiveness of heavy metal ions on chelating ion exchangers," Environmental Technology, vol. 32, no. 8, pp. 805-816, 2011.

[46] V. I. Kuz'Min and D. V. Kuz'Min, "Sorption of nickel and copper from leach pulps of low-grade sulfide ores using purolite S930 chelating resin," Hydrometallurgy, vol. 141, pp. 76-81, 2014. 


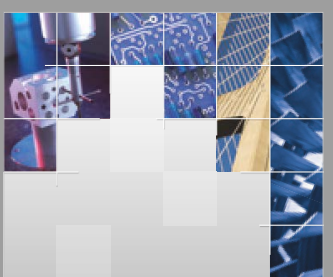

\section{Enfincering}
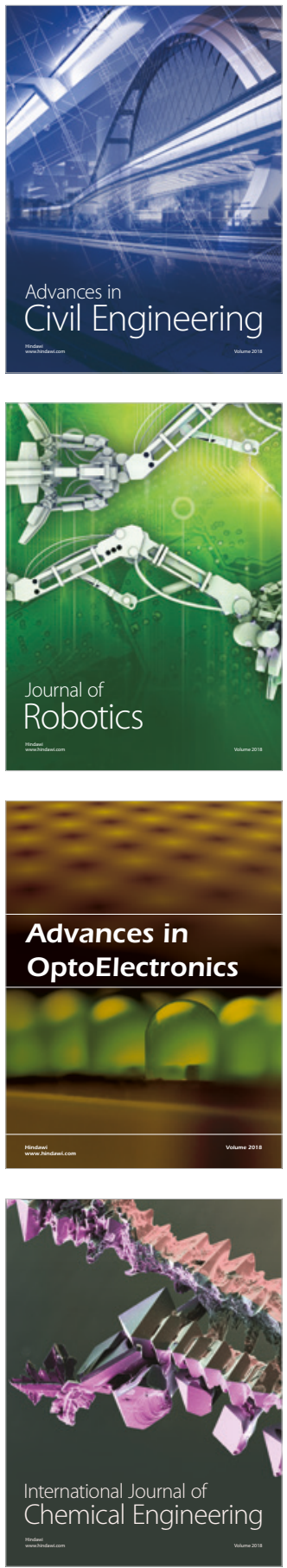

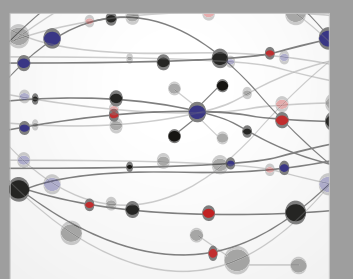

\section{Rotating \\ Machinery}

The Scientific World Journal

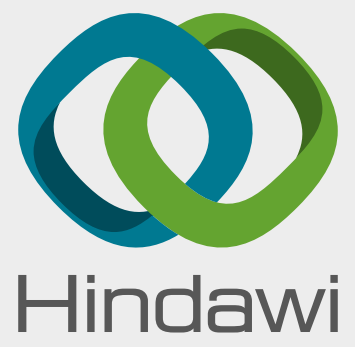

Submit your manuscripts at

www.hindawi.com
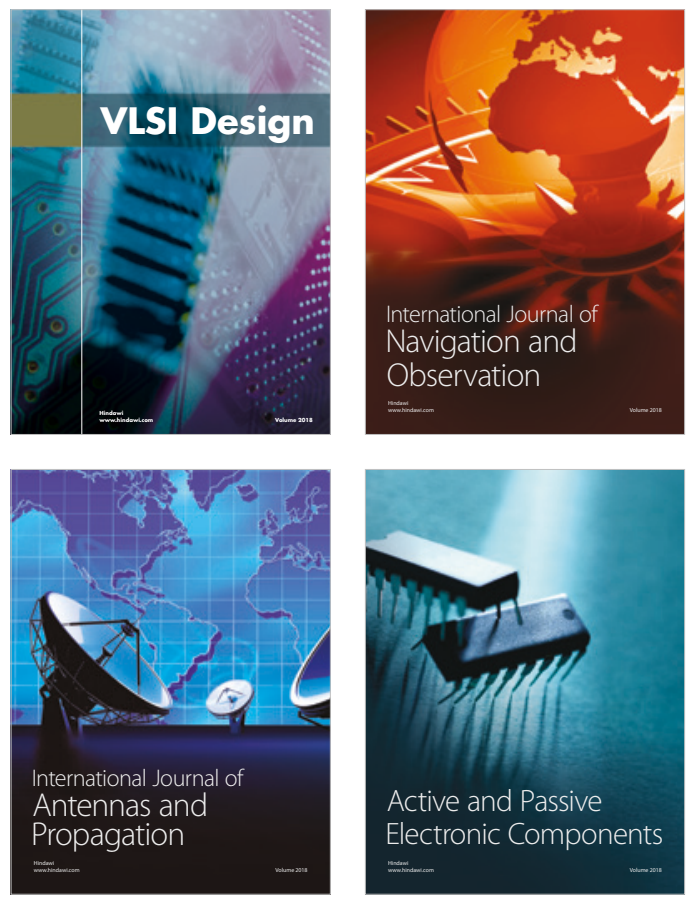
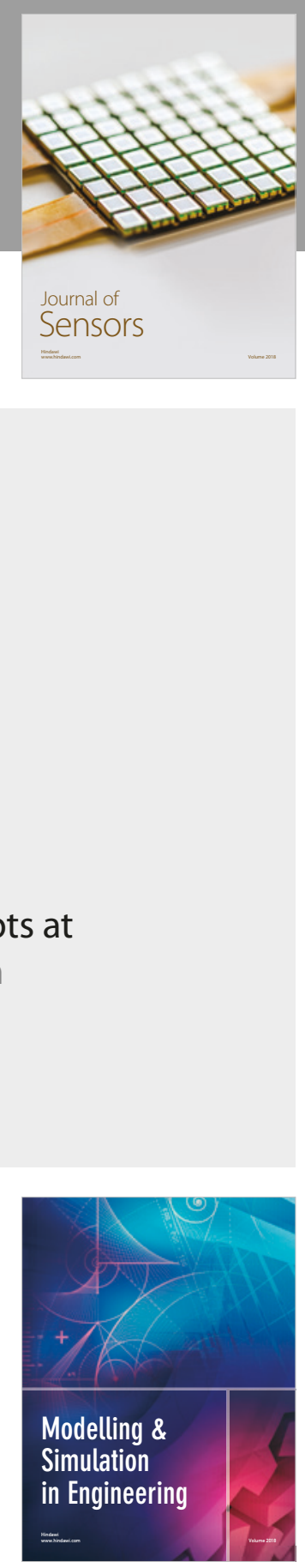

\section{Advances \\ Multimedia}
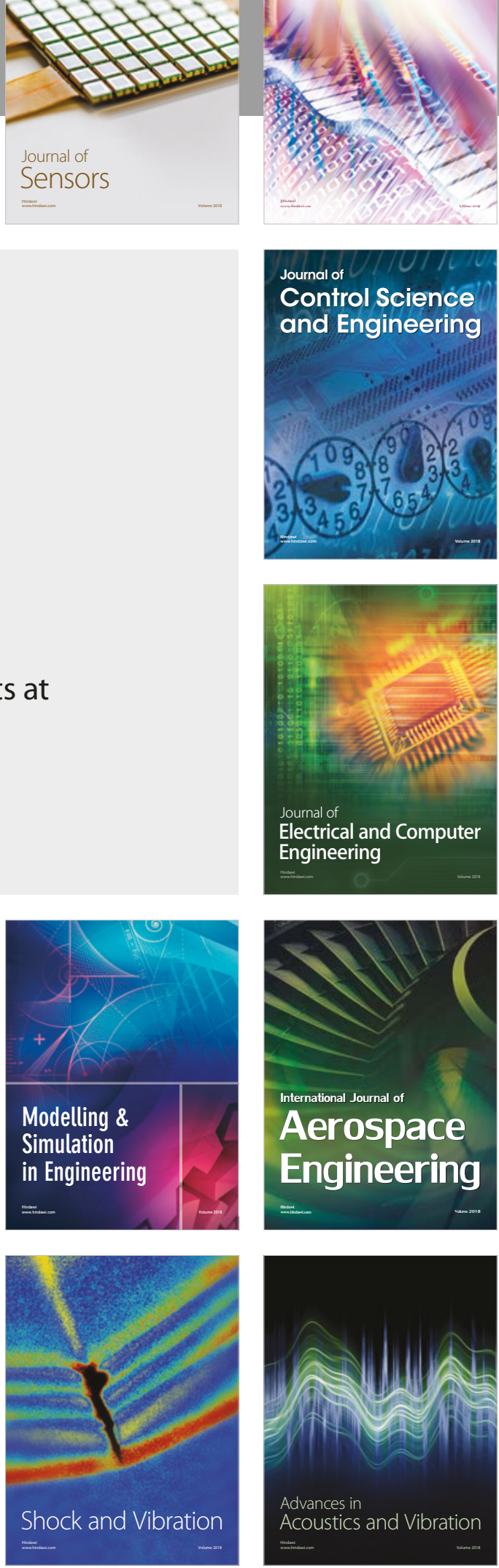